Education in public schools is considered by many to furnish desirable and even essential training for citizenship, apart from that gained by the study of books. The association with those of all classes of society, at an early age and upon a common level, is not unreasonably urged as a preparation for discharging the duties of a citizen. The object of the school laws is not only to protect the state from the consequences of ignorance, but also to guard against the dangers of incompetent citizenship. .5

\title{
TRADE DISPARAGEMENT AND THE "SPECIAL DAMAGE" QUAGMIRE
}

"During all his years in public life Harry Truman never bothered to have his portrait painted. Recently, however, as President, he sat for artist Jay-Wesley Jacobs. The result, Truman's first portrait, is shown here." So claimed Life magazine for November 26, I945. But it appeared that Harry Truman's first portrait had been painted in January I945 by artist Larry Pendleton, and was not that reproduced in Life. An agreement between Life and Pendleton to feature that portrait had not materialized. Plaintiff Pendleton brought suit in Illinois alleging the falsity of the statements and that defendant, notwithstanding knowledge of the falsity, maliciously published said statements with intent to injure plaintiff and plaintiff's reputation as an artist. He claimed damage in the sum of $\$ 100,000.00$. A motion to dismiss was sustained in the

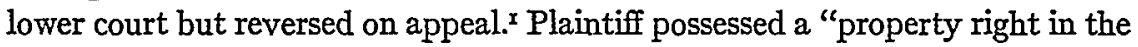
value attained in the painting of the 'first' portrait of Harry S. Truman. . .," and since an "injury to plaintiff's property right was willfully, maliciously and intentionally committed by defendant, there must be a remedy for this wrong to the plaintiff." The court required no allegation and proof of "special" damage. But the dissent saw the action as one of "disparagement" and, surveying the authorities, found that "the publication of falsehoods disparaging the merits, quality, utility or value of another's property is not actionable unless the plaintiff has suffered special damage and pecuniary loss as a direct and natural result of the publication."3 Finding insufficient allegation of "special" damage, ${ }^{4}$ the dissent thought that the complaint should have been dismissed.

and of what constitutes public policy, are not subject to review by the courts. Cremer v. Peoria Housing Authority, 399 Ill. 579, 78 N.E. 2d 276 (1948); People v. Eakin, 383 Ill. 383 , 50 N.E. 2d 474 (1943).

s3 State v. Hoyt, 84 N.H. 38 , I46 Atl. I70 (1929).

I Pendleton v. Time, Inc., 339 Ill. App. I88, 89 N.E. 2 d 435 (I949).

2 Ibid., at 194 and 438 . $\quad 3$ Ibid. See authorities cited notes $1_{3}, x_{5}, 16$ infra.

4 The allegations of damage stated that plaintiff Jost all benefit and advantage accruing to him by reason of his having painted the first portrait of Harry Truman, that plaintiff was made to appear as having false claim to the painting of the first portrait, that plaintiff lost all value in the rights of reproduction of his painting as the first portrait, and that plaintiff lost the commission to do portraits of other prominent persons. Pendleton v. Time, Inc., 339 Ill. App. 188, 19o, 89 N.E. 2 d 435, 437-38 (r949). 
In recent years courts have been confronted with a growing number of "disparagement" actions. In the typical situation the plaintiff is injured in his business or business reputation by false and usually "malicious" utterances to third persons, by word of mouth, or, more commonly, by the printed word. 5 Throughout the cases there is confusion as to the nature of the harm sustained by the plaintiff as well as doubt concerning what allegation and proof of damage is to be required. Redress is made to hinge on the presence or absence of the requirement of allegation and proof of "special" damage. ${ }^{6}$ This requirement in turn depends upon whether the action obtains judicial recognition as disparagement ("special" damage required but unevenly applied);7 as libel or slander affecting one in his business or trade (damage presumed) ; $;^{8}$ as slander or libel not actionable per se ("special" damage required);" or as malicious interference with the property right in trade (no "special" damage required)..$^{\text {to }}$ An examination of these categories not only indicates how "thin partitions do their realms divide," but casts new doubt on the validity and utility of the troublesome "general""special" damage distinction-so basic to defamation law.

A modern definition of disparagement holds: "The publication of false statements disparaging the plaintiff's title to his property, or its quality, or the character or conduct of his business, is actionable if it results in special damage in the form of pecuniary loss due to the refusal of others to deal with him." What

5 Cases cited notes $17,28,34,38$ infra.

${ }^{6}$ Redress may similarly hinge on other requirements that vary with the categories, such as the availability of injunctive relief, statute of limitations period, survival statutes, and presumption of falsity. None of these issues compare in importance with the requirement as to allegation and proof of damage-an integral part of the cause of action. The injunction issue has, however, received considerable litigation. Because of the kinship of disparagement to defamation and the issue of freedom of speech, it was long the law that injunctions would not lie; see Green, Relational Interests, 30 Ill. L. Rev. I, 39-45 (I935); Pound, Equitable Relief Against Defamation and Injuries to Personality, 29 Harv. L. Rev. 640 (IgI5). More recently some courts have permitted the enjoining of disparaging publications; see Jurisdiction of Equity over Libels Affecting Trade, $75 \mathrm{U}$. of $\mathrm{Pa}$. L. Rev. $25^{8}$ ( $\mathrm{rg26}$ ). In so doing, courts tend to emphasize interference with property rights and "unfair competition," and are ignoring the requirement of "special" damage; see Paramount Pictures v. Leader Press, I06 F. 2d 229 (C.A. Ioth, x939); Carter v. Knapp Motor Co., 243 Ala. 600, II So. 2d 383 (r943); Black \& Yates v. Mahogany Ass'n, I29 F. 2d 227 (C.A. 3d, r94r); Lawrence Trust Co. v. Sun-American Pub. Co., 245 Mass. 262, I39 N.E. 655 (r923).

7 Cases cited notes $17,28,35$ infra.

9 Cases cited note 38 infra.

8 Cases cited note 35 infra.

to Cases cited note 45 infra.

Ix Prosser, Torts 1036 (1941); see Rest., Torts \$§ 624-52 (1938); Bower, Actionable Defamation Art. 6r (rgo8); Salmond, Law of Torts 8 I5० (9th ed., 1936); Smith, Disparagement of Property, 13 Col. I. Rev. I3 (Igr3); Wham, Disparagement of Property, 21 Ill. L. Rev. ${ }_{26} 6$ (1926); Nims, Unfair Competition by False Statement and Disparagement, ig Corn. L.Q. 63 (r933). Hibschman, Defamation or Disparagement? 24 Minn. I. Rev. 625 (r940); Chafee, Unfair Competition, 53 Harv. L. Rev. I289 (1940); Handler, Unfair Competition, 21 Iowa L. Rev. 175 (1936); Wood, Disparagement of Title and Quality, 20 Can. Bar Rev. 296 (1942); Slander of Title, 8 Univ. Chi. L. Rev. 370 (194r); Injurious Falsehood, 28 Corn. L.Q. 226 (I943); Injury to Trade Relations by a Non-Competitor, 4 r Ill. L. Rev. 66I (I947). Salmond and Prosser view the tort as somewhat broader than indicated in the text and term it "in- 
is said to distinguish this tort from defamation is the absence of injury to plaintiff's reputation - "the essence of defamatory matter." ${ }^{\prime 2}$ In disparagement the plaintiff must prove the disparaging character of the statements, their communication to third persons, their falsity, and "special" damage in all cases. ${ }^{13}$ The requirement of "special" damage here means that in pleadings and proof "the plaintiff must identify the particular purchasers who have refrained from dealing with him, and specify the transactions of which he claims to have been deprived." "I4 In the tort's infancy as "slander of title," where plaintiff's title to land had been impugned so that he could not dispose of it to prospective purchasers, ${ }^{25}$ the requirement could be easily met. But today where it is typically plaintiff's business custom that is alienated, the rule encounters criticism..$^{16} \mathrm{It}$ is manifestly impossible, where customers are in futuro, unknown and numerous, to plead and prove each specific loss. Yet such is what the courts appear to require. ${ }^{17}$

Inroads have been made upon the arbitrary characterization of "special" damage. In I892 in Ratcliffe v. Evans, Bowen, L. J., treated the concept sensibly when he said: "As much certainty and particularity must be insisted on both in pleading and proof of damage, as is reasonable, having regard to the circumstances and to the nature of the acts themselves by which the damage is done. To insist upon less would be to relax old and intelligible principles. To insist upon more would be the vainest pedantry."18 For the most part these words went unheeded by the American courts, but recently some courts, pressed by

jurious falsehood." "It is an actionable wrong maliciously to make a false statement respecting any person with the result that other persons deceived thereby are induced to act in a manner which causes loss to him." Salmond, Law of Torts at 553 (9th ed., 1936).

"Bower, Actionable Defamation at 240(y) (Ig08). Salmond, Law of Torts, at 553 says: "Both in defamation and injurious falsehood the defendant is liable because he has made a false and hurtful statement respecting the plaintiff; but in one case the statement is an attack upon his reputation, and in the other it is not."

${ }_{23}$ Prosser, Torts I04I-43 (I94I); Bower, Actionable Defamation, art. 6I(3) (Igo8); Smith, Disparagement of Property, 13 Col. L. Rev. 13, I29-31 (1913); Salmond, Law of Torts 555 (gth ed., I936). Malice is frequently said to be essential to the action but it appears rather to mean the absence of privilege. Prosser at 1043; Smith at 2I, I39; Salmond at 555; Bower at 244-46; see Disparagement or Slander of Title, 22 Can. Bar Rev. 47x (I944).

${ }_{4}$ Prosser, Torts ro 45 (194I); see cases cited note ${ }_{7}$ infra and in Smith, Disparagement of Property, I3 Col. L. Rev. 13, I21-24 (1913).

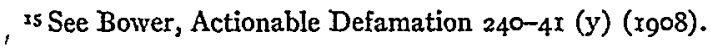

- ${ }^{16}$ Prosser, Torts 1045 (I94I); Green, Relational Interests, 30 Ill. L. Rev. I, 30-3I (1935).

'17 Shaw Cleaners \& Dyers v. Des Moines Dress Club, 215 Iowa Ir30, 245 N.W. 23 I (1932); Denney v. Northwestern Credit Ass'n, 55 Wash. 33I, I04 Pac. 769 (I909); Ward v. Gee, 6I S.W. 2d 555 (Tex. Civ. App., I933); Tower v. Crosby, 214 App. Div. 392, 21 2 N.Y. Supp. 219 (1925); but see Erick Bowman Remedy Co. v. Jensen Salsbery Laboratories, I7 F. 2d 255 (C.A: 8 th, 1926).

${ }_{18}$ [1892] 2 Q.B. $524,532-33$. The court held that allegation and proof of loss of business following the disparagement was sufficient, where the custom was numerous and unknown. 
the otherwise resulting injustice, have looked to the Ratcliffe v. Evans rule, ${ }^{\text {I9 }}$ or, while giving lip-service to the "special" damage requirement, have granted relief on much less. ${ }^{20}$ As a result, the courts are found applying the "special" damage requirement in three ways: to require complete specification of transactions and customers lost;21 to require a showing of loss of business following the disparagement; $; 2$ to require only what the exigencies of the situation will permit. ${ }^{23}$

Disparagement like defamation involves the utterance of words intended to damage. But slanderous imputations affecting the plaintiff in his business, trade, profession or office, are actionable per se. ${ }^{24}$ "'The likelihood of 'temporal' damage in such a case is sufficiently obvious. .. . The object ... is to protect the plaintiff in his office or calling... ."25 Thus it is actionable without proof of damage for a tradesman to be falsely accused of insolvency or a professional of incompetency ${ }^{26}$ - "since these things obviously discredit him in his chosen calling."

x9 Houston Chronicle Pub. Co. v. Martin, 5 S.W. $2 d$ r 70 (Tex. Civ. App., r928), modified ${ }_{64}$ S.W. 2d 816 (Tex. Civ. App., I933); see Erick Bowman Remedy Co. v. Jensen Salsbery Laboratories, I7 F. 2d 255 (C.A. 8th, I926); Craig v. Proctor, 229 Mass. 339, II 8 N.E. 647 (I9I8).

${ }^{20}$ Advance Music Corp. v. American Tobacco Co., I83 Misc. 855, 5 I N.Y.S. 2 d 692 (1944), rev'd 53 N.Y.S. 2d 337 (I945), but affirmed 296 N.Y. 79, 70 N.E. 2d 401 (1945). In the Pendleton case the majority said by way of dictum that if allegations of special damage were required, the allegations of the instant complaint were sufficient. Pendleton v. Time, Inc., 339 Ill. App. I88, 196, 89 N.E. 2d 435, 439 (1949). This despite the fact that not even loss of business was specifically alleged. For an acute discussion of the ambiguity of "special" damage see Bower, Actionable Defamation, art. $I_{3}$, note ( $p$ ), wherein the term actual damage is adopted in place of the "either meaningless or misleading" term "special" damage.

2x Cases cited note $I 7$ supra.

${ }^{22}$ Cases cited note I9 supra. This is apparently the English rule; see Bower, Actionable Defamation, art. I3 note (u) (Ig08). McCormick on Damages 422 (1935) indicates that Ratcliffe v. Evans is good law in American courts where "special" damage to custom through general loss in business is alleged. But the weight of authority appears contra; see cases cited note $\mathrm{r} 7$ supra.

${ }^{23}$ Cases cited note ${ }_{7} 7$ supra.

${ }^{4}$ Prosser, Torts $\$ 92$ (I94I); Bower, Actionable Defamation, art. 12 (rgo8); Salmond, Law of Torts $\$ \S$ 132, I47 (6th ed., I924).

2s Prosser, Torts 802 (I94I). The reason behind the categorizing of slander affecting one in his trade as actionable per se is rarely articulated. It seems probable that as in the other per se categories, i.e., serious crime, loathsome disease, unchastity, the imputation was simply viewed as such that damage was "bound to result." The general attitude toward defamation distinctions is that, "The basis and origin of the demarcation is ... historical and not rational or doctrinal." Bower, Actionable Defamation, art. I 2 note (a) (Ig०8).

${ }^{26}$ Wayne Works v. Hicks Body Co., $x 15$ Ind. App. 10, 55 N.E. $2 d 382$ (I944); DeSeversky v. P. \& S. Publishing, 34 N.Y.S. 2d 284 (1942); Kitograd v. Shapiro, 39 N.Y.S. 2d 959 (r943); Diamond v. Krasnow, 136 Pa. Super. 68, 7 A. 2d 65 (1939); see Salmond, Law of Torts $\$ \S 132$, I47 (6th ed., I924); Prosser, Torts 802-4 (194I); Bower, Actionable Defamation, art. I 2 note (j) (1908).

27 Prosser, Torts 803 (I94I). 
this wrong to that of disparagement, where, if the work or product of the tradesman be falsely accused of defect, "special" damage need yet be proven. ${ }^{28} \mathrm{As}-$ suredly, in the one case and in the other, the words just as "obviously discredit him in his chosen calling." Recognition of the similarity between imputations of disparagement and slanderous imputations affecting one in his trade is forestalled by the irreconcilable requirement of strict proof of damage for the one and the legal presumption of damage for the other. Yet the proximity of the actions cannot realistically be denied. To be sure, it is generally realized that "the principles of law applied to the disparagement of the thing are ... closely analogous to those applied to the defamation of the person." 29 But it is claimed that disparagement does not "involve any injury to the reputation of a person at all, and since this element is of the essence of defamatory matter, it is clearly not defamation." ${ }^{30}$ The concepts are blurring the facts, for if it can be maintained that slander affecting one in his trade is defamatory because injurious to reputation, it must be conceded that disparagement is similarly defamatory. In both cases it is the business or trade that is affected, and in both cases, if reputation be injured at all, it is the trade reputation that suffers. ${ }^{3 x}$ The only distinction is that disparaging words are directed at the plaintiff's trade while slanderous words are directed at plaintiff "in the way of his trade."

\footnotetext{
${ }^{28}$ Hopkins Chemical Co. v. Read Drug \& Chemical Co., x24 Md. 210, 92 Atl. 478 (IgI4); Victor Safe \& Lock Co. v. Deright, I 47 Fed. 2 II (C.A. 8th, I906); General Market Co. v. PostIntelligence Co., Inc., 96 Wash. 575, I65 Pac. 482 (I9I7); Dooling v. Budget Pub. Co., I44 Mass. 258, ro N.E. 809 ( 1887 ); see cases cited notes 34,37 infra where the courts have diffculty distinguishing words disparaging the trade and words defaming the tradesmen. There is good reason for this difficulty, as is further indicated by this passage from Bower, Actionable Defamation at 28-29 (Ig08) where the requirement for the trade slander category are explained: "The slanderous matter must be published of the party defamed, not only in the way of his trade or calling, but also so as to affect his reputation therein ... and the meaning of this latter requirement is that the words must impute something which, if true, would have a natural tendency to injure the plaintiff in the occupation in question. ..."
}

29 Bower, Actionable Defamation, art. 57, note (p) (1908).

$3^{\circ}$ Ibid., at art. 6r, note (y).

${ }^{3 x}$ This is apparently recognized in the English Report of the Committee on the Law of Defamation (Cmd. 7536/48). See Faulks, Report of the Committee on Defamation, $98 \mathrm{~L}$. J. 6II (I948). ". . . it is recommended that in cases of malicious but not defamatory falsehoods causing damage known generally but vaguely as 'actions on the case,' the law, which at present always requires proof of special damage, should be amended to make actionable per se ... (b) such statements, however published, if they were calculated to cause actual pecuniary damage to the plaintiff in his office, profession or trade."

32 Even this distinction becomes untenable in the case of disparagement or defamation of a corporation. Corporations have no reputation in any personal sense, yet have prestige and standing which may be injured. Thus imputations casting aspersions upon the honesty, credit or efficiency of corporations have been held defamatory, Axton-Fisher Tobacco Co. v. Evening Post Co., I69 Ky. 64, I83 S.W. 269 (IgI6); St. James Military Academy v. Gaiser, I25 Mo. $517,28 \mathrm{~S}$.W. $85 \times$ ( 1894 ). Analytically only disparagement of such bodies is possible and courts generally demand allegation and proof of "special" damage. See cases cited notes $x$, 28 supra. 
seem that a requirement of strict proof of damage on the one hand, and a presumption of damage on the other, ought not hinge on such a distinction. Indeed a more tenable alignment would shift the presumption of damage to the case of disparagement, since the injury to trade relations is here accomplished more directly by derogating the trade rather than plaintiff in the way of his trade.

When, in order to avoid the "special" damage requirement, counsel press on the courts words disparaging the product as words defaming their producer, both courts and commentators perceive difficulty. ${ }^{33}$ In such cases the disparaging words as to the product are urged as imputing deception or lack of integrity to their producers. ${ }^{34}$ If convinced, the courts will admit that the remarks are not merely disparaging but defamatory, and, as libel or slander affecting one in his trade, relief will be afforded without the onerous burden of proof. ${ }^{35}$ In such cases, the logic stripped of refinement would appear thus:

$\mathrm{D}$ falsely stated that garments made by $\mathrm{P}$ are defective (mere disparagement requiring proof of "special" damage).

But this implies that $P$ is a cheat,

And since a cheat who makes garments will be viewed as making defective garments,

$\mathrm{P}$ has been defamed in his trade (and damage is presumed)..$^{36}$

It would seem such gymnastics ought not be approved. Perhaps more deserving of approbation are those courts which, somewhat blinded by the lines of dis-

${ }^{33}$ See comments and cases in Prosser, Torts 1038-40 (194I); Hibschman, Defamation or Disparagement, 24 Minn. L. Rev. 625 (I940); Prosser goes so far as noting, "It might be possible to imply some accusation of personal inefficiency or incompetence, at least, in nearly every imputation directed against a business or its product."

34 Rosenberg v. J. C. Penney Co., 30 Cal. App. 2d 609, 86 P. 2d 696 (I939); Shaw Cleaners \& Dyers v. Des Moines Dress Club, 2I5 Iowa II30, 245 N.W. 23 I (1932); National Refining Co. v. Benzo Gas Motor Fuel Co., 2o F. 2d 763 (C.A. 8th, 1927); Erick Bowman Remedy Co. v. Jensen Salsbery Laboratories, I7 F. 2d 255 (C.A. 8th, I926); Dust Sprayer Mfg. Co. v. Western Fruit Grower, I26 Mo. App. 139, 103 S.W. 566 (I907); Tobin v. Alfred M. Best Co., I 20 App. Div. 387, I05 N.Y. Supp. 294 (Ig०7); Holmes v. Clisby, II8 Ga. 820, 45 S.E. 684 (Ig03); Inland Printer Co. v. Economy Half-Tone S. Co., 99 Ill. App. 8 (IgOr); Non Pareil Cork Mfg. Co. v. Keasbey \& Mattison Co., ro8 Fed. 721 (Pa., Igor); Freisinger v. Moore, 65 N.J.L. 286, 47 Atl. 432 (I900); Brooks v. Harison, gI N.Y. 83 (I883).

35 Rosenberg v. J. C. Penney Co., 30 Cal. App. 2d 609, 86 P. 2d 696 (I939); Summit Hotel Co. v. National Broadcasting Co., 336 Pa. 182, 8 A. $2 d 302$ (r939); Larson v. Brooklyn Daily Eagle, I65 App. Div. 4, I5० N.Y. Supp. 464 (IgI4); Tobin v. Alfred M. Best Co., I 20 App. Div. 387 , I05 N.Y. Supp. 294 (1907); Holmes v. Clisby, Ir8 Ga. 820 , 45 S.E. 684 (Ig03); Inland Printer Co. v. Economy Half-Tone Supply Co., 99 Ill. App. 8 (Igor); Freisinger v. Moore, 65 N.J.L. 286, 47 Atl. 432 (Igoo); Craig v. Pueblo Press Pub. Co., 5 Colo. App. 208, 37 Pac. 945 (1894); Landon v. Watkins, 6I Minn. I37, 63 N.W. 6r5 (1895).

${ }^{36}$ Compare Freisinger v. Moore, 65 N.J.L. 286, 47 Atl. 432 (Ig00); Brooks v. Harison, gI N.Y. 83, 9 I (I883); Rosenberg v. J. C. Penney Co., 30 Cal. App. 2d 609, 86 P. 2 d 696 (I939); Tobin v. Alfred M. Best Co., $x 20$ App. Div. 387, 105 N.Y. Supp. 294 (1907); Holmes v. Clisby, II8 Ga. 820, 45 S.E. 684 (IgO3). 
tinction, cannot tell the difference between words defaming the plaintiff in his trade and words disparaging plaintiff's trade. ${ }^{37}$

It has been indicated that if a disparagement action were viewed by the court as slander affecting one in his business, the rigid demand of allegation and proof of "special" damage would be displaced by the legal presumption of damage. Similarly, if disparagement were viewed as libel, damage would be presumed, for it is hornbook law that all libel is actionable per se. In disparagement there is no distinction between oral and written imputations. However, since much disparagement is accomplished by print, many courts fail to distinguish it from libel as to the requirement of allegation and proof of "special" damage. Looking to the question of whether the words are defamatory on their face, as determinative on the damage issue, the courts lump disparagement and libel requiring "innuendo" or "inducement" together, and require proof of "special" damage as to both. ${ }^{38}$ Thus the requirement of allegation of "special" damage has been substituted for the requirement of allegation of "special" facts in the "innuendo" libel situations. These courts are assisting many others in a movement which threatens to obliterate that most basic defamation distinction between oral and written matter. Courts are today holding that if the alleged libel is not defamatory on its face but |requires explanation by "inducement" or "innuendo," it is not libelous per se but requires proof of "special" damage. ${ }^{39}$ Others have held imputations libelous per se only when falling into one of the familiar per se categories of slander. $4^{\circ}$ Such distortion of orthodox defamation law together with the discordant treatment of disparagement cases indicate judicial dissatisfaction with the principles governing damages in defamation.

The view taken by the majority in the Pendleton case avoids the requirement of "special" damage but does not escape the problem. The dissent argued with justification that the action was properly one of disparagement; that allegation

37 Compare Cohen v. Eisenberg, I73 Misc. 1089, I9 N.Y.S. 2d 678 (I940), aff'd 260 App. Div. Ior 4, 24 N.Y.S. 2d I004 (1940); Henkle v. Schaub, 94 Mich. 542, 54 N.W. 293 (1893); Chiatovich v. Hanchett, 96 Fed. 681, 687 (C.C. Nev., 1899) aff'g 88 Fed. 873 (I898); Gardella v. Log Cabin Products Co., 89 F. 2d 89x (C.A. 2d, r937); Carroll v. Paramount Pictures, 3 F.R.D. 95 (N.Y., I942).

${ }^{38}$ See Ellsworth v. Martindale-Hubbell Law Directory, 66 N.D. 578,268 N.W. 400 (1936); Rosenberg v. J. C. Penney Co., 30 Cal. App. 2d 609, 86 P. 2d 696 (I939); Shaw Cleaners \& Dyers v. Des Moines Dress Club, 215 Iowa Ir 30,245 N.W. 23 I (1932); National Refining Co. v. Benzo Gas Motor Fuel Co., 20 F. 2d 763 (C.A. 8th, I927); Erick Bowman Remedy Co. v. Jensen Salsbery Laboratories, I7 F. 2d 255 (C.A. 8th, I926); Dust Sprayer Mfg. Co. v. Western Fruit Grower, I26 Mo. App. I39, ro3 S.W. 566 (rgo7); cf. Advance Music Corp. v. American Tobacco Co., 183 Misc. 645 , 50 N.Y.S. $2 d 287$ (r944).

${ }^{39}$ See the many cases cited in Carpenter, Libel Per Se in California and Some Other States, I7 So. Calif. I. Rev. 347 (I944); Burke, Libel Per Se, I4 Calif. L. Rev. 6I (I925).

${ }^{40}$ Rachels v. Deener, I82 Ark. 93I, 33 S.W. 2 d 39 (I930); Harrison v, Burger, 2I 2 Ala. 670, I03 So. 842 (I925); Landati v. Stea, 44 R.I. 303, II7 Atl. 422 (I922); Tennessee Coal, Iron \& Ry. Co. v. Kelly, 163 Ala. 348, 50 So. 1008 (xg०9); Briggs v. Brown, 55 Fla. 4r7, 46 So. 325 (I908); see Carpenter, op. cit. supra note 39 , at $355^{-56}$. 
of "special" damage was required but insufficiently set forth in the pleadings. ${ }^{4 x}$ But the majority viewed the issue of "special" damage as foreign to the case, relying on Tuttle v. Buck ${ }^{42}$ and Doremus v. Hennessy $y^{43}$ to sustain the action as malicious interference with the property right of doing business. 44 There is some support for application of this theory to the Pendleton situation, but the scant precedent is further weakened by the confusion that attends it. 45 Yet, a similar approach to actions of disparagement is preferred by commentators dissatisfied with the existing law of defamation..$^{4}$ They advocate considering the tort as simply one form of interference with economic relations. ${ }^{47}$ But with courts so disinclined to talk in terms of the interference with such intangibles, $4^{8}$ it is almost certain that talk of "property" would multiply, 49 dispute as to the requirement of "special" damage increase, ${ }^{50}$ and the troublesome concept of "malice" lend its weight to the confusion.

Throughout that area of law affording redress for injurious words, the rules as to allegation and proof of damage emerge as ultimate arbiters of award or denial of relief. When these rules come to be viewed as essentially arbitrary they can only be attacked and broken by commentators and courts..$^{51}$ And

4x Pendleton v. Time, Inc., 339 Ill. App. I88, 89 N.E. 2d 435 (1949).

4 107 Minn. 145, xr9 N.W. 946 ( 1909 ).

13176 III. 608, 52 N.E. 924 (1898).

44 Pendleton v. Time, Inc., 339 Ill. App. 188, 89 N.E. $2 d 435$ (I949).

45 See Advance Music Corp. v. American Tobacco Co., 183 Misc. 855,51 N.Y.S. 2d 692 (I944), rev'd 53 N.Y.S. $2 d 337$ (I945), aff'd 296 N.Y. 79, 70 N.E. 2d 40I (1946); Stebbins v. Edwards, IOI Okla. I88, 224 Pac. 714 (I924); Adriance Platt \& Co. v. National Harrow Co., I21 F. 827 (C.A. 2d, 1903); Lawrence Trust Co. v. Sun-American Pub. Co., 245 Mass. 262, 139 N.E. 655 (I923); cf. Al Raschid v. News Syndicate Co., 265 N.Y. I, 4, I9r N.E. 713, 714 (I934).

${ }^{46}$ Prosser, Torts ${ }^{0} 37$ (r94I); Smith, Disparagement of Property, I3 Col. L. Rev. I2r, 129-3I (I913).

47 Prosser, Torts ro49 (I94); Green, Relational Interests, 30 Ill. L. Rev. I, 29-45 (I935); see Smith, Disparagement of Property, I3 Col. L. Rev. 12I, I30-32 (r9r3).

${ }^{8}$ Courts cling to the old concepts even when recognizing "new" actions in the nature of interference. This is doubtless the reason why disparagement cases are so full of "interference with property" discussion. Similarly, in a related area, the leading case of Lumley v. Gye, 2 El. \& Bl. 216 , Ir8 Eng. Rep. 749 (Q.B., 1853), found the court speaking of the interference with contractual relations as interference with property.

49 Ibid. "Property" seems to be the "tangible" concept capable of being spread to embrace almost any intangible relation. It appears undesirable in disparagement; see Prosser, Torts I04I (194I). In Dudley v. Briggs, I4I Mass. 582, 6 N.E. 7 I 7 (1886), defendant falsely represented that plaintiff would not publish a directory thereby inducing third persons to advertise in and subscribe for defendant's directory, but no legal right of plaintiff's was held to have been invaded since his intention to publish a directory was held not to constitute property.

so The more courts view the action as malicious interference, the less will "special" damage be required, and the greater will be the conflict with disparagement decisions. Compare in the Pendleton case the majority (interference) with the minority (disparagement) where the sole issue turned on whether "special" damage was required.

sx See criticism and proposals in Prosser, Torts 777-78, 803-9 (I94I); McCormick, Damages 416 (1935); Bower, Actionable Defamation 318-22 (r908); Paton, Reform and The English 
though there is widespread agreement that the prevailing rules should go, there is meager accord on those which should take their place. Much that is proposed would simply retain the concepts but rearrange the categories..$^{52}$ It might be rewarding to explore the possibilities of abolishing the "general"-"special" damage categories completely, rather than seek to realign them. If by so doing, attention can be directed to all the facts comprising the injury rather than to the words alleged to have produced it, then would the law have moved toward realistic treatment of words intended to damage.

\section{DISCOVERY OF GOVERNMENT DOCUMENTS UNDER THE FEDERAL RULES}

The advent of the liberal discovery provisions of the Federal Rules of Civil Procedure ${ }^{x}$ has brought in its wake a renewed discussion of an old problem: when should documents in the possession of the executive departments of the government be considered privileged from disclosure? ${ }^{2}$ The resolution of this question involves not only the balancing of the respective rights and needs of private litigants and the government in its various litigious capacities, ${ }^{3}$ but also a delineation of the powers of the executive and the courts in an area where their duties overlap. 4

Law of Defamation, 33 Ill. L. Rev. 669 (r939); Carr, The English Law of Defamation, I8 L.Q. Rev. 255, 388 (1902); Donnelly, Law of Defamation-Proposals for Reform, 33 Minn. L. Rev. 609 (r949); Committee on the Law of Defamation: The Porter Report, r 2 Modern L. Rev. 2I 7 (r949); Faulks, op. cit. supra note 3 r.

${ }_{52}$ See for examples, Paton, op. cit. supra note $5 \mathrm{I}$; Donnelly, op. cit. supra note $5 \mathrm{I}$; Faulks, op. cit. supra note 3 I.

I Rule 34,28 U.S.C.A. foll. $\$ 2072$ (I950): "Upon motion of any party showing good cause therefor ... the court in which an action is pending may ( $I$ ) order any party to produce and permit the inspection and copying or photographing . . . of any designated documents, papers, books, accounts, letters, photographs, objects, or tangible things, not privileged, which constitute or contain evidence material to any of the matters within the scope of the examination permitted. ..." Rules 26-32, together with Rule 45 (b) and (d), authorize the issuance of similar orders to persons not parties to the action; these orders are also subject to the defense of privilege. Park Ridge Corp. v. Elias, 3 F.R.D. 93 (I943). As for the use of other defenses provided by the Rules, in the context of government litigation, see Pike and Fischer, Discovery against Federal Administrative Agencies, 56 Harv. L. Rev. II25 (1943); to this list should be added the "work-product" limitation laid down in Hickman v. Taylor, 329 U.S. 495 (I947).

For a general discussion of the discovery procedure, see Pike and Willis, Federal Discovery in Operation, 7 Univ. Chi. L. Rev. 297 (I940); Holtzoff, Instruments of Discovery under Federal Rules, 4 X Mich. L. Rev. 205 (I942).

2 United States v. Burr, 25 Fed. Cas. I, 37, I9I (C.C. Ky., I806).

3 Recent cases suggest that the treatment of the government's claim of privilege might depend on whether the government is acting in a sovereign or a proprietary capacity. See cases cited note 46 infra.

4 See text at notes $I_{3}-I_{5}$ infra. 